\title{
THE ROLE OF THE VISEGRAD GROUP'S MACROECONOMIC DEVELOPMENT IN EXCHANGE RATE DETERMINATION
}

\author{
Kitty Klacsánová 1 (i) \\ Mária Bohdalová ${ }^{2}$ (1)
}

DOI: https://doi.org/10.31410/LIMEN.S.P.2019.61

\begin{abstract}
Shifts in the values of macroeconomic indicators influencing the exchange rate of a particular currency may signal future monetary policy decisions. Several problems or opportunities can be exposed in terms of international trade, investment and other activities involving the conversion of a country's currency by monitoring the macroeconomic development. This paper aims to analyze a wide range of macroeconomic indicators with a potential effect on exchange rate movements in the Visegrad Group between 2000 and 2017. It provides an overview of economic indicators with a significant impact on the volatility of four currencies, the Czech crown, Hungarian forint, Polish zloty and the euro against US Dollar. The presented exchange rate models incorporate the USD/EUR since the Slovak Republic is part of the Eurozone. The paper analyzes the contribution of the Slovak Republic to the development of the euro as well as the importance of various endogenous and exogenous macroeconomic indicators in the Visegrad Group's exchange rate determination. The paper tests besides the traditional influence factors the relevance of economic complexity and corruption, which do not serve as a focal point in empirical exchange rate theories. The findings indicate that the end year spot exchange rates of the Czech crown, Hungarian forint and the euro, are merely influenced by the GDP per capita measured in current prices. For this reason, they have a significant role in predicting exchange rate movements across the Visegrad Group. Additionally, the last chapter compares the results of the employed methods. Overall, regarding the values of explained variance and the root mean square of error, the paper points out that the models established for the Czech crown and the euro are the most accurate.
\end{abstract}

Keywords: Indicator, GDP, Regression, Outliers, Complexity.

\section{INTRODUCTION}

$\mathrm{T}$

he research aimed to identify significant influence factors with respect to the future development of the Visegrad Group's US Dollar exchange rates.

Exchange rate fluctuations determine the volume and direction of exports and imports. The development of exchange rates is linked to their possible steep changes, which represent a substantial risk for investors and affects the particular county's competitiveness (Ramasamy \& Abar, 2015, p. 261-281, Jeon et al., 2017, p. 112-159). Exchange rates develop depending on the country's economy, as macroeconomic variables are unstable over time (Salvatore, 2012, p. 486-487, Cihelková, 2008, p. 150-155). The monetary exchange rate models of Frenkel-Bilson and Dornbusch-Frankel (Frenkel, 1978, p. 3-4) consider relative money supply, relative real income, interest rate and inflation differentials to be the most important macroeconomic indicators in exchange rate determination.

\footnotetext{
$1 \quad$ Comenius University in Bratislava, Faculty of Management Odbojárov 10, Bratislava, Slovak Republic

2 Comenius University in Bratislava, Faculty of Management Odbojárov 10, Bratislava, Slovak Republic
} 
Other factors also play an important role in the development of exchange rates. Chen and Rogoff (Y. Chen \& Rogoff, 2003,p. 134) pointed out the relationship between commodity prices considering their sample. Furthermore, Ferraro, Rogoff and Rossi (Ferraro et al., 2015, 116-141) proved that incorporating oil prices in exchange rate models can increase their predictive ability, therefore they assume that the relationship between changes in oil prices and exchange rates is significant. According to Shiu-Sheng Chen and Cheng-Che Hsu (Chen \& Hsu, 2019, p. 700), the situation on the stock market is critical for the determination of future exchange rate movements. Overall, the determinants of exchange rates can be fundamental or temporary (Bostan et al., 2018, p. 2).

In this paper, we decided to analyse the influence of the selected macroeconomic factors on exchange rates. The next chapter presents our proposed model established from the data. In the following chapters, we present our results. Our conclusions can be found in the last chapter. We see the contribution of this paper in revealing key macroeconomic factors affecting the evolution of exchange rates in the Visegrad Countries.

\section{METHODOLOGY AND DATA}

This paper analyses the economic development of the Visegrad Group through the changes in selected macroeconomic indicators. We employed two methods for regression analyses, namely the multivariate OLS and the robust regression methods that used the Hubert weighting method. The established models incorporate the yearly values of economic variables from 2000 to 2017. In the case of Slovakia, the analyses represent this country's contribution to the common currency euro. We transformed the nominal GDP and considered its logarithmic form in each analysis.

The research tested the following exchange rate model:

$$
\begin{aligned}
F X_{E Y}= & \beta_{0}+\beta_{1} \times C P I+\beta_{2} \times L T I N T+\beta_{3} \times S H P R I C E+\beta_{4} \times E M P+\beta_{5} \times H O U S E C O S T_{R E N T}+ \\
& \beta_{6} \times \log G D P p c_{\text {current }}+\beta_{7} \times e c i+\beta_{8} \times \text { Corruption_Score }+e
\end{aligned}
$$

where

$F X_{E Y}$ represents the end year spot exchange rates of the Czech crown, Hungarian forint, Polish zloty and the euro against US Dollars,

CPI represents the consumer price index, measuring inflation through the changes in the consumer price index,

LTINT represents the long-term interest rates of government bonds with a 10 -year maturity,

SHPRICE represents the share price index, which measures the changes in the values of common stock traded nationally as well as internationally,

EMP represents the employment rate of the population in a particular country,

HOUSECOST_RENT represents an index, which measures the changes in the rent costs of houses, LogGDPpc_current represents the nominal GDP per capita measured in USD,

eci represents the economic complexity index, measuring the knowledge base of an economy by considering the intensity of knowledge in production processes and products that a particular country export,

Corruption_Score measures the degree of corruption in a country on the interval from 0 to 100 , where the countries with low scores are those with more corrupt practices. 
The sources of the above listed indicators follow from the databases of the Bank of International Settlements, Bank of England, Transparency International, Organisation for Economic Co-operation and Development and the Observatory for Economic Complexity. Each indicator, in an index form, considers the year 2015 as the base year. The selection of these factors was based on our preliminary cluster analysis to avoid the problem of multicollinearity.

The presented analyses in this paper verify the relationship between macroeconomic variables and exchange rates. Moreover, we decided to analyse economic complexity and corruption as contemporary economic conditions are determined by a certain level of knowledge and misuse of public power for private benefit. These indicators do not create a focal point to a great extent in researches. In this context, the Czech Republic proved to be the most complex owing to its production processes and during the analysed period the least complex products had been produced in Poland. According to the mean values of corruption scores, the most corrupt country was the Slovak Republic, followed by the Czech Republic.

\section{SIGNIFICANT ECONOMIC INDICATORS IN EXCHANGE RATE DETERMINATION}

In this part, we investigated how the selected macroeconomic indicators influence the development of the Czech crown, Hungarian forint, Polish zloty, and the euro. We established regression models to point out the differences and the co-movements in terms of the selected indicators. Table 1 lists the results of the ordinary least square regression for each country.

After comparing the models, for the four countries of the Visegrad Group, we found that in terms of the coefficient of determination, they are the most accurate for the Czech crown and the euro. $93.11 \%$ and $95.47 \%$ of the variance in the dependent variable was predictable by independent variables in our proposed model for the exchange rates USD/CZK and USD/EUR. The model for the euro is the best since the Adjusted R-square for this currency is the highest, 0.9145. On the contrary, for the Hungarian forint and the euro, the values of the R-square statistic were lower, $81.88 \%$ and $83.97 \%$ respectively (see Table 3 ).

The exchange rates of the Czech crown, Hungarian forint and the euro are influenced by one common macroeconomic indicator, which is the nominal GDP per capita. The coefficients of this independent variable acquire negative values in each of the models. A one per cent increase in the logarithms of the nominal GDP per capita in a particular country results in a decrease in the values of exchange rates of the Visegrad Group excluding the Polish zloty. Additionally, the results indicate that there exists a statistically significant relationship between the USD/ EUR exchange rate and the Slovak Republic's economic complexity. Following an increase of the Slovak Republic's economic complexity, which is linked to the diversity of products that the country exports along with their ubiquity, the USD/EUR exchange rate increases depreciating the euro against the US Dollar. Therefore, if the Slovak Republic became more diversified and produced fewer products with great ubiquity, then the euro would weaken against the dollar.

For Poland, it is not possible to establish a representative model for its exchange rate against US Dollars as none of the macroeconomic variables has a significant impact on the USD/PLN exchange rate, regarding the composition of the model. 
Table 1. Parameter estimates of the OLS regression

\begin{tabular}{|c|c|c|c|c|c|}
\hline & Variable & Estimate & Standard Error & t Value & $\operatorname{Pr}>|t|$ \\
\hline \multirow{9}{*}{ CZK } & Intercept & 184.3242 & 52.4466 & 3.5100 & 0.0066 \\
\hline & CPI & 0.5848 & 0.4707 & 1.2400 & 0.2454 \\
\hline & LTINT & -0.3199 & 0.8609 & -0.3700 & 0.7188 \\
\hline & SHPRICE & 0.0117 & 0.0417 & 0.2800 & 0.7850 \\
\hline & EMP & 0.1686 & 0.5198 & 0.3200 & 0.7531 \\
\hline & HOUSECOST_RENT & 0.1264 & 0.1038 & 1.2200 & 0.2542 \\
\hline & logGDPpc_current & -18.8088 & 5.4053 & -3.4800 & 0.0069 \\
\hline & ECI & -2.6080 & 13.7387 & -0.1900 & 0.8537 \\
\hline & Corruption_Score & 0.0397 & 0.2758 & 0.1400 & 0.8887 \\
\hline \multirow{9}{*}{ HUF } & Intercept & $1,270.6284$ & 554.0709 & 2.2900 & 0.0475 \\
\hline & CPI & -2.6031 & 5.3167 & -0.4900 & 0.6361 \\
\hline & LTINT & 1.7784 & 12.3817 & 0.1400 & 0.8890 \\
\hline & SHPRICE & 0.1521 & 0.4365 & 0.3500 & 0.7355 \\
\hline & EMP & 5.9992 & 6.2977 & 0.9500 & 0.3657 \\
\hline & HOUSECOST_RENT & 0.6583 & 1.5418 & 0.4300 & 0.6794 \\
\hline & logGDPpc_current & -178.4597 & 52.3020 & -3.4100 & 0.0077 \\
\hline & eci & 153.3120 & 151.3145 & 1.0100 & 0.3374 \\
\hline & Corruption_Score & 0.1545 & 2.0879 & 0.0700 & 0.9426 \\
\hline \multirow{9}{*}{ PLN } & Intercept & 7.5713 & 5.9065 & 1.2800 & 0.2319 \\
\hline & $\mathrm{CPI}$ & -0.0867 & 0.0528 & -1.6400 & 0.1351 \\
\hline & LTINT & -0.0813 & 0.0666 & -1.2200 & 0.2534 \\
\hline & SHPRICE & -0.0088 & 0.0065 & -1.3500 & 0.2087 \\
\hline & EMP & 0.0529 & 0.0731 & 0.7200 & 0.4878 \\
\hline & HOUSECOST_RENT & -0.0394 & 0.0323 & -1.2200 & 0.2531 \\
\hline & logGDPpc_current & -0.7320 & 0.7692 & -0.9500 & 0.3661 \\
\hline & eci & 1.3780 & 1.1742 & 1.1700 & 0.2707 \\
\hline & Corruption_Score & 0.0567 & 0.0310 & 1.8300 & 0.1004 \\
\hline \multirow{9}{*}{ EUR } & Intercept & 3.3895 & 1.3520 & 2.5100 & 0.0335 \\
\hline & $\mathrm{CPI}$ & -0.0052 & 0.0108 & -0.4800 & 0.6406 \\
\hline & LTINT & -0.0218 & 0.0185 & -1.1800 & 0.2682 \\
\hline & SHPRICE & -0.0013 & 0.0007 & -1.8200 & 0.1013 \\
\hline & EMP & 0.0028 & 0.0178 & 0.1600 & 0.8794 \\
\hline & HOUSECOST_RENT & -0.0061 & 0.0056 & -1.0800 & 0.3084 \\
\hline & logGDPpc_current & -0.4521 & 0.1974 & -2.2900 & 0.0478 \\
\hline & eci & 1.2230 & 0.5190 & 2.3600 & 0.0428 \\
\hline & Corruption_Score & 0.0185 & 0.0126 & 1.4700 & 0.1768 \\
\hline
\end{tabular}

Source: Analysis on the data

\section{COMPARING THE RESULTS OF THE OLS AND ROBUST REGRESSION}

To point out and eliminate outliers and influential observations we compared the results of the ordinary least square regression with the robust regression (Table 3). After employing the robust regression method (Table 2), we found the substantial economic indicator in exchange rate determination of the Czech crown and the Hungarian forint, which is the nominal GDP, likewise as in the OLS regression. On the contrary, for Poland and the Slovak Republic, the robust analysis yielded different results. The Polish zloty and the euro are commonly influenced by the development of: 
- House costs - Higher rent prices in Poland and the Slovak Republic are reflected in their currency's appreciation against US Dollars. The zloty's and the euro's strengthening can be present due to increased investments of foreign subjects in Polish and Slovakian real estate. The USD/PLN and the USD/EUR exchange rates appreciate after investors convert their dollars into the national currencies of these two countries, zloty and euro.

- The nominal GDP - The Polish zloty and the euro strengthen their position against the US Dollar when the nominal GDP of Poland and Slovakia increases by one percentage. Thus, economic growth has a positive impact on the zloty and the euro in the case if a country aims to achieve its currency's appreciation against the US Dollar, to make imports cheaper for domestic consumers.

Additionally, in the USD/PLN exchange rate determination the following macroeconomic indicators play a key role:

- Inflation - We received discussable results regarding inflation, as higher levels of consumer price index appreciated the zloty, during the analysed period, on average by 0.10 .

- Share prices - An increase in this indicator causes a decrease in the value of USD/PLN, appreciating the Polish currency. The better situation on the shares market represented by higher prices has an incentive for investors holding US Dollars to buy Polish shares until they reach their peak and then the prices along with the returns begin to fall.

- Rate of employment - an increase in the rate of employment in Poland by one percentage depreciates the zloty on average by 0.16 . The reason behind this can be that a higher rate of employment is linked to a greater disposable income of domestic consumers enabling them to invest internationally, namely in USD, which then weakens the country's currency.

The USD/EUR exchange rate merely deviates, besides the rent prices and nominal GDP owing to the changes also in:

- Long term interest rates - Increasing interest rates of government bonds in the Slovak Republic appreciate the USD/EUR exchange rate. Favourable opportunities to achieve better returns on investment into the country's debt might create an incentive among investors holding US Dollars to convert them to euros and enjoy higher yields when disposing of bonds. On the other hand, the US dollar weakens its position against the euro.

- Economic complexity - The findings indicate that rising economic complexity of the Slovak Republic leads to the depreciation of the euro against USD. One of the reasons could be the growing prices of more complex goods weakening the motivation of consumers to purchase them. Therefore, decreased demand for Slovakian products leads to the consumers', especially those holding euros, new orientation on the US market. Eventually, the euro supply increases after the exchange.

\section{CONCLUSION}

This research aimed to find several macroeconomic indicators that have a significant influence on the development of exchange rates in the period from 2000 to 2017. We employed two methods for data analysis, the OLS and the robust regression. The former method yielded similar results for three countries, the Czech Republic, Hungary and the Slovak Republic. Only one of the eight macroeconomic indicators influence significantly the end year spot exchange rates of these countries, which is the nominal GDP per capita. 
Table 2. Parameter estimates of the robust regression

\begin{tabular}{|c|c|c|c|c|c|}
\hline & Variable & Estimate & Standard Error & Chi-Square & Pr $>$ ChiSq \\
\hline \multirow{9}{*}{ CZK } & Intercept & 184.3206 & 57.1551 & 10.4000 & 0.0013 \\
\hline & CPI & 0.5849 & 0.5129 & 1.3000 & 0.2542 \\
\hline & LTINT & -0.3201 & 0.9382 & 0.1200 & 0.7330 \\
\hline & \begin{tabular}{|l|} 
SHPRICE \\
\end{tabular} & 0.0117 & 0.0455 & 0.0700 & 0.7967 \\
\hline & EMP & 0.1685 & 0.5665 & 0.0900 & 0.7661 \\
\hline & HOUSECOST_RENT & 0.1264 & 0.1131 & 1.2500 & 0.2638 \\
\hline & logGDPpc_current & -18.8069 & 5.8905 & 10.1900 & 0.0014 \\
\hline & eci & -2.6112 & 14.9722 & 0.0300 & 0.8616 \\
\hline & Corruption_Score & 0.0397 & 0.3006 & 0.0200 & 0.8949 \\
\hline \multirow{9}{*}{ HUF } & Intercept & $1,270.6280$ & 554.0709 & 5.2600 & 0.0218 \\
\hline & CPI & -2.6031 & 5.3167 & 0.2400 & 0.6244 \\
\hline & LTINT & 1.7784 & 12.3817 & 0.0200 & 0.8858 \\
\hline & SHPRICE & 0.1521 & 0.4365 & 0.1200 & 0.7275 \\
\hline & EMP & 5.9992 & 6.2977 & 0.9100 & 0.3408 \\
\hline & HOUSECOST_RENT & 0.6583 & 1.5418 & 0.1800 & 0.6694 \\
\hline & logGDPpc_current & -178.4600 & 52.3020 & 11.6400 & 0.0006 \\
\hline & eci & 153.3120 & 151.3145 & 1.0300 & 0.3110 \\
\hline & Corruption_Score & 0.1545 & 2.0879 & 0.0100 & 0.9410 \\
\hline \multirow{9}{*}{ PLN } & Intercept & 4.0084 & 2.7966 & 2.0500 & 0.1518 \\
\hline & CPI & -0.1062 & 0.0250 & 18.0500 & $<.0001$ \\
\hline & \begin{tabular}{|l|} 
LTINT \\
\end{tabular} & -0.0502 & 0.0315 & 2.5300 & 0.1116 \\
\hline & \begin{tabular}{|l|} 
SHPRICE \\
\end{tabular} & -0.0155 & 0.0031 & 25.1700 & $<.0001$ \\
\hline & EMP & 0.1661 & 0.0346 & 23.0100 & $<.0001$ \\
\hline & HOUSECOST_RENT & -0.0345 & 0.0153 & 5.1000 & 0.0239 \\
\hline & logGDPpc_current & -0.7205 & 0.3642 & 3.9100 & 0.0479 \\
\hline & eci & -0.0665 & 0.5559 & 0.0100 & 0.9047 \\
\hline & Corruption_Score & 0.0211 & 0.0147 & 2.0600 & 0.1510 \\
\hline \multirow{9}{*}{ EUR } & Intercept & 3.2723 & 0.9244 & 12.5300 & 0.0004 \\
\hline & CPI & -0.0072 & 0.0074 & 0.9500 & 0.3299 \\
\hline & LTINT & -0.0474 & 0.0126 & 14.0200 & 0.0002 \\
\hline & SHPRICE & -0.0007 & 0.0005 & 1.9600 & 0.1612 \\
\hline & EMP & -0.0089 & 0.0122 & 0.5300 & 0.4653 \\
\hline & HOUSECOST_RENT & -0.0094 & 0.0038 & 6.0000 & 0.0143 \\
\hline & logGDPpc_current & -0.2695 & 0.1350 & 3.9900 & 0.0459 \\
\hline & eci & 1.0409 & 0.3549 & 8.6000 & 0.0034 \\
\hline & Corruption_Score & 0.0109 & 0.0086 & 1.5900 & 0.2069 \\
\hline
\end{tabular}

Source: Analysis on the data

Table 3. Summary of the OLS and robust regression

\begin{tabular}{|c|c|c|c|c|}
\cline { 2 - 5 } \multicolumn{1}{c|}{} & CZK & HUF & PLN & EUR \\
\hline OLS R-Square & 0.9311 & 0.8188 & 0.8397 & 0.9547 \\
\hline OLS Adj R-Sq & 0.8698 & 0.6577 & 0.6971 & 0.9145 \\
\hline $\begin{array}{c}\text { Robust Regression } \\
\text { R-Square }\end{array}$ & 0.8583 & 0.7954 & 0.7604 & 0.8634 \\
\hline
\end{tabular}

Source: Analysis on the data 
The results of the robust regression showed the differences between countries as well as verified the accuracy of the OLS analysis by weighting each observation. For the Czech Republic, the Huber weighting method proved that the results of the OLS method are close to that of the robust regression. Additionally, employing the OLS and the robust regression, we received the same results for Hungary as well. Therefore, we can state that according to our data the nominal GDP is the most important indicator in predicting exchange rates for these two countries. The models for the Slovak Republic and Poland are the least accurate since there are three to four observations with noticeably reduced weights form those of the OLS method, which assigns a weight one to each observation.

Furthermore, one additional indicator, namely the rent prices, represents a common factor for Poland and the Slovak Republic. The robust regression revealed three other indicators affecting the zloty and two for the euro. The indicator with the greatest impact on the euro, based on the values of the regression coefficients, is not the nominal GDP as in the case of the other three countries, but the economic complexity index in the Slovak Republic. Its one-unit increase depreciates the euro on average by 1.04 .

In terms of the variance explained and predictive ability, the best models were built for the Czech crown and the euro. The presented analyses can serve as a base point for investment decisions in the Czech crown, Hungarian forint, Polish zloty and the euro. They can also represent a signal for organizations, to hedge their open positions and avoid losses due to steep changes in macroeconomic variables influencing the US Dollar exchange rate of their national currency.

\section{REFERENCES}

Bostan, I., Toderașcu (Sandu), C., \& Firtescu, B.-N. (2018). Exchange Rate Effects on International Commercial Trade Competitiveness. Journal of Risk and Financial Management, 11(2), 19. https://doi.org/10.3390/jrfm11020019

Chen, S.-S., \& Hsu, C.-C. (2019). Do stock markets have predictive content for exchange rate movements? Journal of Forecasting, 38(7), 699-713. https://doi.org/10.1002/for.2592

Chen, Y., \& Rogoff, K. (2003). Commodity currencies. Journal of International Economics, 60(1), 133-160. https://doi.org/10.1016/S0022-1996(02)00072-7

Ciheková, E., Frait, J., \& Varazin, F. (2008). Mezinárodní ekonomie II. Praha, Czech Republic: C. H. Beck.

Ferraro, D., Rogoff, K., \& Rossi, B. (2015). Can oil prices forecast exchange rates? An empirical analysis of the relationship between commodity prices and exchange rates. Journal

of International Money and Finance, 54(C), 116-141.

Frenkel, J. A. \& CLEMENTS W. K. Exchange Rates in the 1920's: A Monetary Approach. NBER working paper series. Working Paper No. 290., https://www.nber.org/papers/w0290.pdf

Jeon, B. N., Zheng, D., \& Zhu, L. (2017). Exchange Rate Exposure: International Evidence from Daily Firm-Level Data. Journal of Economic Integration, 32(1), 112-159. https://doi. org/10.11130/jei.2017.32.1.112

Meese, R. \& Rogoff, K. (1983) Empirical Exchange Rate Models of the Seventies: Do They Fit Out of Sample? Journal of International Economics vol. 14

Ramasamy, R., \& Abar, S. K. (2015). Influence of Macroeconomic Variables on Exchange Rates. Journal of Economics, Business and Management, 3(2), 276-281. https://doi.org/10.7763/ JOEBM.2015.V3.194

Salvatore, D. (2012) International Economics. New York, New York: John Wiley \& Sons. 